\title{
腹板の耐荷力に関する一考察
}

\section{A CONSIDERATION ON THE STRENGTH OF WEBPLATES}

\author{
小西 一 郎*.白 石 成 人**.渡 辺 英 一***
}

By Ichiro Konishi, Naruhito Shiraishi and Eiichi Watanabe

\section{1. まえがき}

最近構造工学は目ざをしい進歩を遂げつつあるが，そ の原因の一つに構造用鋼材の材質の向上, 改善がある。 しかし高張力鋼が普通の鋼に比較して常に有利であると はいえないことにも留意しなくてはならない。たとえば トラスを初めとする棒材からなる骨組構造物の圧縮部材 に高張力鋼を用いたとしても座屈現象に対しては断面を 小さくすることによる利益は少なく，有益ではない。さ て, それでは板構造を主体とする構造物に関してはどの ようなものであろらか。確かに各国の鋼構造物設計示方 書を読めば, 高張力鋼の使用による有益性は大きくはな いがこれは線形理論に立脚した結論に過ぎないことに注 意すべきである。プレート ガーダーなど板構造のうち でも主要部である腹板はフランジや諸補剛材などによっ て連結的に結合されているから，かなり安定であると思 われるので, 高張力鋼使用によるメリットを検討するこ とは大きな価值を持っている。この観点から板の座屈が その耐荷力とどのような関係にあるのかを座屈後の板の 挙動解析によって明らかにし, この結果が実際のプレー トガーダーの腹板の安定性を考えるうえでいかなる工 学的意味を持つかを考察しようと思う。

\section{2. 本研究の意義亡問題点の提起}

対象とする構造物は板構造のうちでも最も簡単なもの の一つであるプレート ガーダーである。いまそのプレ ートガーダーのうちでも最も簡単な両端単純支持のも のを考えてみれば，これが鉛直荷重を受けるとスパンの 中央部では曲げが，支点の近傍ではせん断力の影響が卓 越することが考えられる。これら両極端な場合について それぞれのパネル，すなわち上下フランジと左右 2 つの 垂直補剛材によって囲まれる腹板の部分に着目し, これ を単なる板と見なし種々の境界条件を理想的に与えて解 析を行ない, これらの結果よりもっと複雑な状態にまで 言及するのが過去における，いな現在でも採用されてい るやむを得ない手法である。またさらに, 座屈後の板の 挙動についても有限変形理論 ${ }^{1)}{ }^{21}$, 3) に基づいていくらか

* 正会員 工博 京都大学教授 工学部土木工学教室

** 正会員 工博 京都大学助教授 工学部土木工学教室

*** 学生会員 工修 京都大学大学院工学研究科博士課程学生 土木工学専攻
の限られた簡単な場合を取扱った論文が発表せられてい る。しかし筆者らの見る限り,一方向に圧縮力を受ける 有限な板については十分な解析がつくされているが，そ の他の場合，たとえば純曲げや純せん断を受ける板につ いての解析は, 有益な資料としてわれわれが利用できる 段階にはいっていないように思われる。本論文では四辺 単純支持の板がそれぞれ純せん断, 純曲げを受ける場合 を想定し有限変形理論を用いて解析した。

\section{（1）せん断力荷重を受ける腹板についての問題点"}

せん断座屈後には腹板にいわゆる斜張力の場ができる が,このことは航空工学の分野において大きく取り扱わ れて来た。しかし航空機部材中の板と橋構造としてのプ レートガーダーの腹板との間には一見相当な類似点が あるがまた重大な相違点が存在する。すなわち航空機で は板はそれよりもはるかに剛な補剛材により支持されて いるため，あたかも障子紙と木わくの関係に類似してい る。ところが一般のプレート ガーダーの腹板の剛性と それを支持する各境界部材の剛性には著しいへだたりが ないのが普通である。ゆえに航空工学において発展した 斜張力理論はそのままプレート ガーダーの挙動解析に 用いることは問題である。われわれはまず一番簡単な場 合, すなわち板が四辺単純支持されていて純せん断を受 けたとき果たして斜張力の場が現出できるか, またそれ がどれくらい簡略化された斜張力理論による解析結果と 異なるのかを考察したい。

\section{（2）曲げを受ける腹板についての問題点}

過去に行なわれた実験結果より, 曲げを受けるパネル の耐荷力は腹板自身の座屈後の強度にはあまり左右され ずにむしろ境界の圧縮フランジの座屈などによって大き く影響を受けることが報告されている ${ }^{5,6)}$ 。曲げを受け るプレートガーダーが破壊する原因としては

i ）圧縮フランジの鉛直方向への座屈

ii）フランジの横方向への座屈

iii）圧縮フランジの局部的なねじれ座屈

が考えられるが，このうち i）はほとんど問題にならな いし，また ii）は実際の橋梁構造において床板などと十 分堅固に結合しておけばまず問題にならないだろう。よ って iii）に対して十分な考慮がなされるべきであり， この点に関する研究は数多く行なわれていて非常に重要 であると思われるが，本論文は特に腹板の挙動を中心に 
解析するという方針をとっているためにあえてこの問題 を取り扱わないことにする。

\section{Marguerre, Kármán の非線形偏微分方程} 式を用いた板の後座屈挙動の解析

Marguerre の方程式はつぎの 2 式から成る7)

$$
\begin{aligned}
& \nabla^{4} w= \frac{h}{D}\left[\frac{\partial^{2} F}{\partial y^{2}} \frac{\partial^{2}}{\partial x^{2}}\left(w+w_{0}\right)+\frac{\partial^{2} F}{\partial x^{2}} \frac{\partial^{2}}{\partial y^{2}}\right. \\
&\left.\therefore\left(w+w_{0}\right)-2 \frac{\partial^{2} F}{\partial x \partial y} \frac{\partial^{2}}{\partial x \partial y}\left(w+w_{0}\right)\right] \\
& \cdots \cdots \cdots \cdots \cdots \cdots \cdots \cdots \cdots \cdots \cdots \cdots \cdots \cdots \cdots \cdots \cdots \cdots \cdots \cdots \cdots \\
& \nabla^{4} F=E\left(\frac{\partial^{2} w}{\partial x \partial y}-\frac{\partial^{2} w}{\partial x^{2}} \frac{\partial^{2} w}{\partial y^{2}}+2 \frac{\partial^{2} w_{0}}{\partial x \partial y}\right. \\
&\left.\times \frac{\partial^{2} w}{\partial x \partial y}-\frac{\partial^{2} w_{0}}{\partial x^{2}} \frac{\partial^{2} w}{\partial y^{2}}-\frac{\partial^{2} w_{0}}{\partial y^{2}} \frac{\partial^{2} w}{\partial x^{2}}\right)
\end{aligned}
$$

（1）境界にそって一様な大きさのせん断応力 $\tau$ を受 ける初期たわみを有する四辺単純支持の長方形 板の後座屈挙動 $(\text { 図一1 })^{8)}$

a) 基礎方程式の誘 図-1

導問題を簡単にす るため任意の境界辺に そったこれに垂直な方 向の直応力の代数和は 0 として, その直応力 につり合うだけの拘束 カが外から作用するも のと考える。

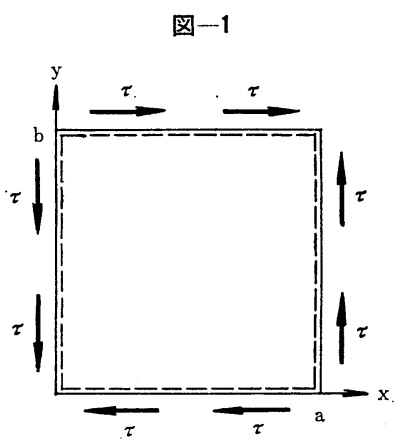

条件式は

$$
\begin{aligned}
& w=0, \frac{\partial^{2} w}{\partial y^{2}}+\nu \frac{\partial^{2} w}{\partial x^{2}}=0 \\
& \text { along } y=0 \& y=b \cdots(2-\mathrm{a}) \\
& w=0, \frac{\partial^{2} w}{\partial x^{2}}+\nu \frac{\partial^{2} w}{\partial y^{2}}=0 \\
& \text { along } x=0 \& x=a \cdots(2-\mathrm{b}) \\
& \int_{0}^{b} \tilde{\sigma}_{x} d y=0 \quad \text { along } x=0 \& x=a \cdots(2-\mathrm{c}) \\
& \int_{0}^{a} \tilde{\sigma}_{y} d x=0 \quad \text { along } y=0 \& y=b \cdots(2-\mathrm{d}) \\
& \tilde{\tau}_{x y}=\tau \quad \text { along all boundaries } \cdots(2-\mathrm{e})
\end{aligned}
$$

いまたわみ $w$, 初期たわみ $w_{0}$ をつぎのように展開で きるものと考える。

$$
\begin{aligned}
& w=h \sum_{m}^{\infty} \sum_{n}^{\infty} b_{m n} \sin \frac{m \pi x}{a} \sin \frac{n \pi y}{b} . \\
& w_{0}=h \sum_{m}^{\infty} \sum_{n}^{\infty} a_{m n} \sin \frac{m \pi x}{a} \sin \frac{n \pi y}{b}
\end{aligned}
$$

ただし $, m, n=1,2,3$,

$b_{m n}$ はこれから求めるべき未知数であって $a_{m n}$ は与え られる定数である。そこでまず条件式 (2-a)〜 (2-e) を 用いて式 (1-b) を応力関数 $F$ について篇密に解き, 外
力 $\tau$ と末知数 $b_{m n}$ で表わしつぎに Galerkin の近似理 論をもって式 (1-a) を解くことにする。たわみを式 (3), (4) のように正弦級数で展開したので式 (2-a), (2-b) は 自動的に満足される。いま式 (3)，（4）を式 (1-b) 人 代入すれば簡単に

$$
\nabla^{4} F=\left(E h^{2} \pi^{4} / a^{2} b^{2}\right) \sum_{p=0}^{\infty} \sum_{q=0}^{\infty} C_{p, q} \cos \frac{p \pi x}{a} \cos \frac{q \pi y}{b}
$$

となる。この解 $F$ として

$$
F=-\tau x y+E h^{2} \sum_{p=0}^{\infty} \sum_{q=0}^{\infty} \Phi_{p, q} \cos \frac{p \pi x}{a} \cos \frac{q \pi y}{b}
$$

を選べばこれは残りの条件式（2-c)，(2-d)，(2-e）を 満足することがわかる*。ただし

$$
\Phi_{p, q}=\beta^{2} C_{p, q} /\left(p^{2}+\beta^{2} q^{2}\right)^{2}, \beta=a / b
$$

つぎに $F$ を用いて式 (1-a) を近似的に解くことを試み る。すなち

$$
\begin{aligned}
& \int_{0}^{a} \int_{0}^{b}\left\{\nabla^{4} w-\frac{h}{D}\left[\frac{\partial^{2} F}{\partial y^{2}} \frac{\partial^{2}}{\partial x^{2}}\left(w+w_{0}\right)+\frac{\partial^{2} F}{\partial x^{2}}\right.\right. \\
& \left.\times \frac{\partial^{2}}{\partial y^{2}}\left(w+w_{0}\right)-2 \frac{\partial^{2} F}{\partial x \partial y} \frac{\partial^{2}}{\partial x \partial y}\left(w+w_{0}\right)\right] \\
& \times \sin \frac{r \pi x}{a} \sin \frac{s \pi y}{b} d x d y=0
\end{aligned}
$$

ただし $r, s=1,2,3, \cdots \cdots$

この式によりつぎの基本式が導かれる。

$$
\begin{aligned}
& \frac{\pi^{4}}{4 \beta^{2}}\left(r^{2}+\beta^{2} s^{2}\right)^{2} b_{r s}-\frac{2 \beta b^{2} h}{D} \tau \sum_{m}^{m \neq r} \sum_{n}^{n \neq s} \\
& \cdot \frac{m n r s}{\left(m^{2}-r^{2}\right)\left(n^{2}-s^{2}\right)}\left[(-1)^{m-r}-1\right]\left[(-1)^{n+s}-1\right] \\
& \times\left(a_{m n}+b_{m n}\right)-\frac{3}{4} \pi^{4}\left(1-\nu^{2}\right) \sum_{m}^{\infty} \sum_{n}^{\infty}\left(a_{m n}+b_{m n}\right) \\
& \times\left\{[m(n+s)-n(m+r)]^{2} \Phi_{m+r, n+s}\right. \\
& -[m(n+s)-n(m-r)]^{2} \Phi_{m-r, n+s} \\
& -[m(n+s)+n(r-m)]^{2} \Phi_{r-m, n+s} \\
& -[m(n-s)-n(m+r)]^{2} \Phi_{m+r, n-s} \\
& +[m(n-s)-n(m-r)]^{2} \Phi_{m-r, n-s} \\
& +[m(n-s)+n(r-m)]^{2} \Phi_{r-m, n-s} \\
& -[m(s-n)+n(m+r)]^{2} \Phi_{m+r, s-n} \\
& +[m(s-n)+n(m-r)]^{2} \Phi_{m-r, s-n} \\
& \left.+[m(s-n)-n(r-m)]^{2} \Phi_{r-m, s-n}\right\}=0
\end{aligned}
$$

ただし

$$
\begin{aligned}
& \Phi_{p, q}(p<0 \text { or } q<0)=0 \\
& r, s=1,2,3, \cdots \cdots \cdots \cdots \cdots
\end{aligned}
$$

初めにたわみ $w$, 初期たわみ $w_{0}$ を無限級数の形に展 開したが実際問題としてこれでは解くことが困難なので

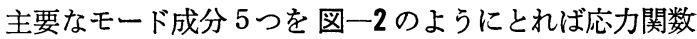
の項 $\Phi_{p, q}$ の数は 図一3のように 21 個となることがわ

$$
\text { * } \quad \tilde{\sigma}_{x}=\frac{\partial^{2} F}{\partial y^{2}}, \quad \tilde{\sigma}_{y}=\frac{\partial^{2} F}{\partial x^{2}}, \quad \tilde{\tau}_{x y}=-\frac{\partial^{2} F}{\partial x \partial y}
$$



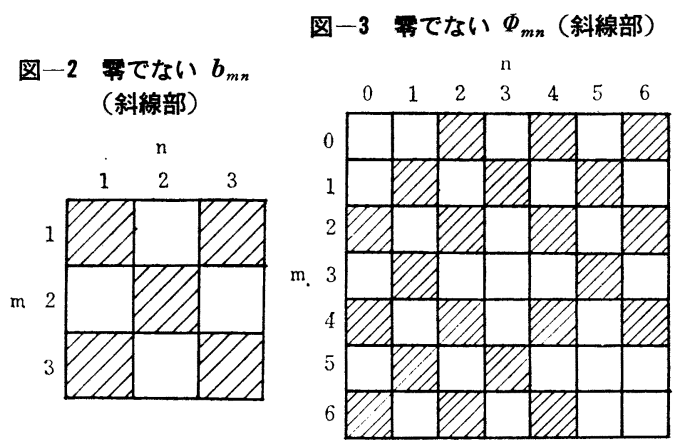

表-1

\begin{tabular}{|c|c|}
\hline$i j$ & $\Phi_{i, j}$ \\
\hline $0 \quad 2$ & $\begin{array}{l}0.03125 b_{11}^{2}+0.00625 a_{11} b_{11}-0.0625 b_{11} b_{13}-0.0625 a_{11} b_{13} \\
-0.5625 b_{31} b_{33}+0.28125 b_{31}^{2}\end{array}$ \\
\hline $0 \quad 4$ & $\begin{array}{l}0.140625 b_{31} b_{33}+0.03125 b_{22}{ }^{2}+0.015625 b_{11} b_{13} \\
+0.015625 a_{11} b_{13}\end{array}$ \\
\hline 06 & $0.0034722 b_{13}{ }^{2}+0.03125 b_{33}{ }^{2}$ \\
\hline 11 & $-1.0 b_{13} b_{22}-1.0 b_{22} b_{31}$ \\
\hline 13 & $0.04 b_{11} b_{22}+0.04 a_{11} b_{22}+0.16 b_{22} b_{31}$ \\
\hline 15 & $0.0236686 b_{13} b_{22}+0.0532544 b_{22} b_{31}$ \\
\hline 20 & $\begin{array}{l}0.03125 b_{11}^{2}+0.0625 a_{11} b_{11}-0.0625 b_{11} b_{31}-0.0625 a_{11} b_{31} \\
-0.5625 b_{13} b_{33}+0.28125 b_{13}^{2}\end{array}$ \\
\hline 22 & $\begin{array}{l}0.0625 b_{11} b_{13}+0.0625 a_{11} b_{13}+0.0625 a_{11} b_{31}+0.0625 b_{11} b_{31} \\
-0.25 b_{13} b_{31}\end{array}$ \\
\hline 24 & $\begin{array}{l}-0.0025 b_{11} b_{13}+0.0225 b_{11} b_{33}+0.0625 b_{13} b_{31}-0.0025 a_{11} b_{13} \\
+0.0225 a_{11} b_{33}\end{array}$ \\
\hline 26 & $0.0225 b_{13} b_{33}$ \\
\hline 31 & $0.04 b_{11} b_{22}+0.04 a_{13} b_{22}+0.16 b_{13} b_{22}$ \\
\hline 35 & $-0.0034602 b_{13} b_{22}$ \\
\hline 40 & $\begin{array}{l}0.015625 b_{11} b_{31}+0.140625 b_{13} b_{33}+0.015625 a_{11} b_{31} \\
+0.03125 b_{22}{ }^{2}\end{array}$ \\
\hline 42 & $\begin{array}{l}-0.0025 b_{11} b_{31}+0.0225 b_{11} b_{33}+0.0625 b_{13} b_{31}-0.0025 a_{11} b_{31} \\
+0.0225 a_{11} b_{33}\end{array}$ \\
\hline 44 & $-0.015625 b_{13} b_{31}$ \\
\hline 46 & $-0.0033284 b_{13} b_{31}$ \\
\hline $5 \quad 1$ & $0.0236686 b_{22} b_{31}+0.0532544 b_{22} b_{33}$ \\
\hline 53 & $-0.0034602 b_{22} b_{31}$ \\
\hline $6 \quad 0$ & $0.03125 b_{33}{ }^{2}+0.0034722 b_{31}{ }^{2}$ \\
\hline 62 & $0.0225 b_{31} b_{33}$ \\
\hline 64 & $-0.003328 b_{31} b_{33}$ \\
\hline
\end{tabular}

かる。

簡単な場合，すなわち正方形板でしかも初期たわみ $w_{0}$ が

$$
w_{0}=a_{11} \sin \frac{\pi x}{a} \cos \frac{\pi y}{b}
$$

で与えられる場合を考えてみよう。表一1によって式 (8) は

$$
\text { (1) }
$$

$-1.465202 X+0.05348172 \lambda Y+0.500000 K^{2} V$

$+0.500000 K^{2} W-1.500000 K X^{2}-4.260000 K V^{2}$
$-4.260000 K W^{2}-1.280000 K Y^{2}-1.620000 K Z^{2}$ $+1.500000 K X V+1.500000 K X W+4.680000 K Y Z$ $+4.680000 \mathrm{KWZ}-2.000000 \mathrm{KVW}-0.500000 X^{3}$ $+0.750000 X^{2} V+0.750000 X^{2} W-4.260000 X V^{2}$ $-4.260000 X W^{2}-1.280000 X Y^{2}-1.620000 X Z^{2}$ $-2.000000 X Y W+4.680000 X V Z+4.680000 X W Z$ $-20.25000 V W Z+6.500000 V W^{2}+6.500000 V^{2} W$ $-3.560000 V Y^{2}-3.560000 W Y^{2}=0$

(2)

$-23.44322 Y+(0.053481715 K+0.053481715 X$ $-0.09626709 \mathrm{~V}-0.09626709 \mathrm{~W}+0.17328076 Z$ ) 2 $-1.280000 K^{2} Y-2.560000 K X Y-7.120000 K Y W$ $-7.120000 \mathrm{KYV}-1.280000 X^{2} Y-7.120000 X Y V$ $-7.120000 X Y W-24.816557 Y Z W$

$-24.81656 Y Z V+27.81015 Y V^{2}-27.81015 Y W^{2}$ $-8.000000 Y^{3}-15.337267 Y^{2}=0$

(3)

$-118.68132 Z+0.1732808 \lambda Y+0.090000 K^{2} V$ $+0.090000 K^{2} W-0.900000 K^{2} Z-2.520000 K X Z$ $+4.680000 \mathrm{KXV}+4.680000 \mathrm{KXW}$

$-42.75000 K V W+2.34000 X^{2} V+2.340000 X^{2} W$ $-1.620000 \mathrm{X}^{2} Z-42.75000 \mathrm{XVW}+20.25000 \mathrm{~W}^{3}$ $+20.25000 V^{3}-40.50000 Z^{3}-86.60982 Z V^{2}$

$-86.60982 Z W^{2}-12.40828 Y^{2} V-12.40828 Y^{2} W$ $-15.33727 Y^{2} Z=0$

(4)

$-36.63004 V-0.09626709 \lambda Y+0.500000 K^{2} X$ $-2.010000 K^{2} V+0.09000 K^{2} Z-1.000000 K^{2} W$ $-8.520000 K X V+0.750000 K X^{2}-2.000000 K X W$ $-3.560000 K Y^{2}+0.250000 X^{3}-4.260000 X^{2} V$ $+6.500000 \mathrm{KW}^{2}+4.680000 \mathrm{KXZ}-22.50000 \mathrm{KZW}$ $+13.00000 \mathrm{KVW}-1.000000 X^{2} W+2.340000 X^{2} Z$ $-3.560000 X Y^{2}+6.500000 Z W^{2}-22.50000 X W Z$ $+13.00000 X V W-20.50000 V^{3}+60.75000 Z V^{2}$ $-86.60982 Z^{2} V-27.81015 Y^{2} V-16.00000 Y^{2} W$ $-29.50000 V W^{2}-12.40828 Y^{2} Z=0$

(5)

$-36.63004 W-0.09626709 Y+0.500000 K^{2} X$ $-2.010000 K^{2} W+0.090000 K^{2} Z-1.000000 K^{2} V$ $+0.750000 K X^{2}-8.520000 K X W-2.000000 K X V$ $+4.680000 \mathrm{KXV}-22.50000 \mathrm{KZV}$

$+13.00000 \mathrm{KVW}-1.000000 \mathrm{X}^{2} V+13.00000 \mathrm{XVW}$ $-20.50000 W^{3}+60.75000 Z W^{2}-86.60982 Z^{2} W$ $-27.81015 Y^{2} W+2.340000 X^{2} Z-3.560000 X Y^{2}$ $+6.500000 K^{2}-3.560000 K Y^{2}+0.250000 X^{3}$ $-4.260000 X^{2} W+6.500000 X V^{2}-22.50000 X V Z$ $-16.00000 Y^{2} V-29.50000 V^{2} \mathrm{~W}-12.40828 Y^{2} Z$ $=0$ 
となる。ただし $\lambda=b^{2} h \tau / D$,

$$
\begin{aligned}
& K=a_{11}, \quad X=b_{11}, \quad Y=b_{22}, Z=b_{33}, \quad V=b_{13}, \\
& W=b_{31}
\end{aligned}
$$

式 (9) は五元三次連立代数方程式であるがさらに $b_{13}$ と $b_{31}$ の対称性を考慮して四元方程式とすることができ る。

b）諸応力の算出 板厚に関して一様に生ずる応力 を $\tilde{\sigma}_{x}, \tilde{\sigma}_{y}, \tilde{\tau}_{x y}$ とすれば式 (6) を微分することによっ てそれぞれ

$$
\begin{aligned}
\tilde{\sigma}_{x}= & \frac{\partial^{2} F}{\partial y^{2}}=-\left(E h^{2} \pi^{2} / b^{2}\right) \sum_{p=0}^{\infty} \sum_{q=0}^{\infty}\left(q^{2} \Phi_{p, q}\right) \\
& \times \cos \frac{p \pi x}{a} \cos \frac{q \pi y}{b} \cdots \cdots \cdots \cdots \cdots(10-\mathrm{a}) \\
\tilde{\sigma}_{y}= & \frac{\partial^{2} F}{\partial x^{2}}=-\left(E h^{2} \pi^{2} / b^{2}\right) \sum_{p=0}^{\infty} \sum_{q=0}^{\infty}\left(p^{2} \Phi_{p, q}\right) \\
& \times \cos \frac{p \pi x}{a} \cos \frac{q \pi y}{b} \cdots \cdots \cdots \cdots \cdots(10-\mathrm{b}) \\
\tilde{\tau}_{x y}= & -\frac{\partial^{2} F}{\partial x \partial y}=\tau+\left(E h^{2} \pi^{2} / a b\right) \sum_{p=9}^{\infty} \sum_{q=0}^{\infty} \cdot \\
& \cdot\left(p \cdot q \Phi_{p}, q\right) \sin \frac{p \pi x}{a} \sin \frac{q \pi y}{b} \cdots(10-\mathrm{c})
\end{aligned}
$$

c) 境界辺の相対変位

$$
\begin{aligned}
{[u]_{x=0}^{x=a}=} & \int_{0}^{a}\left[\frac{1}{E}\left(\frac{\partial^{2} F}{\partial y^{2}}-\nu \frac{\partial^{2} F}{\partial x^{2}}\right)-\frac{1}{2}\left(\frac{\partial w}{\partial x}\right)^{2}\right. \\
& \left.-\frac{\partial w_{0}}{\partial x} \frac{\partial w}{\partial x}\right] d x \cdots \cdots \cdots \cdots \cdots(11-\mathrm{a}) \\
{[v]_{y=0}^{y=b}=} & \int_{0}^{b}\left[\frac{1}{E}\left(\frac{\partial^{2} F}{\partial x^{2}}-\nu \frac{\partial^{2} F}{\partial y^{2}}\right)-\frac{1}{2}\left(\frac{\partial w}{\partial y}\right)^{2}\right. \\
& \left.-\frac{\partial w_{0}}{\partial y} \frac{\partial w}{\partial y}\right] d y \cdots \cdots \cdots \cdots \cdots(11-\mathrm{b})
\end{aligned}
$$

式（11）において $\beta=1$ とおくと

$$
\begin{aligned}
{[u]_{x=0}^{x=a}=} & -\frac{\pi^{2} h^{2}}{8 b}\left(b_{11}{ }^{2}+10 b_{13}{ }^{2}+2 a_{11} b_{11}+4 b_{22}{ }^{2}\right. \\
& \left.+9 b_{33}{ }^{2}\right)=[v]_{\substack{y=b \\
y=0}}^{y=\ldots \ldots \cdots \cdots \cdots \cdots \cdots \cdots \cdots \cdots \cdots \cdots(12) ~}
\end{aligned}
$$

すなわち Edge の相対変位は境界にそって一定である。

(2) 一方向に面内曲げモーメント $\boldsymbol{M}$ を受ける初期 たわみを有する四 辺単純支持の長方 形板の後座屈挙動 (図-4)

前の場合と同じく, 荷重 を受けない方の境界辺にそ ったこれに垂直な方向の直 応力の代数和は 0 とする。 この場合条件式は

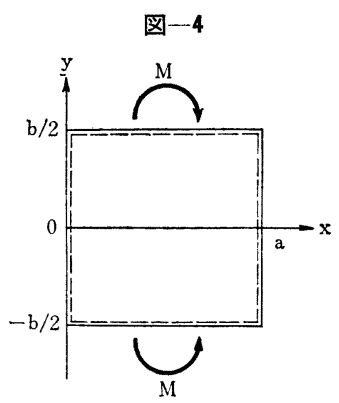

$$
\begin{aligned}
& w=0, \frac{\partial^{2} w}{\partial y^{2}}+\nu \frac{\partial^{2} w}{\partial x^{2}}=0 \\
& \text { along } y= \pm b / 2 \cdots(13-\mathrm{a}) \\
& w=0, \frac{\partial^{2} w}{\partial x^{2}}+\nu \frac{\partial^{2} w}{\partial y^{2}}=0 \\
& \text { along } x=0, a \cdots(13-\mathrm{b})
\end{aligned}
$$

$$
\begin{array}{lr}
M=-h \int_{0}^{a} \tilde{\sigma}_{y} x d x & \text { along } y= \pm b / 2 \cdots(13-\mathrm{c}) \\
h \int_{-b / 2}^{b / 2} \tilde{\sigma}_{x} d y=0 & \text { along } x=0, a \cdots(13-\mathrm{d}) \\
\tilde{\tau}_{x y}=0 \quad \text { along } & \text { all boundaries } \cdots(13-\mathrm{e})
\end{array}
$$

の 5 式である。

いま初期たわみ $w_{0}$ ，たわみ 展開できるものとする。

$$
\begin{aligned}
& w_{0}=h \sum_{m} \sum_{n} a_{m n} \sin \frac{m \pi x}{a} \cos \frac{n \pi y}{b} \\
& w=h \sum_{m} \sum_{n} b_{m n} \sin \frac{m \pi x}{a} \cos \frac{n \pi y}{b} .
\end{aligned}
$$

前の場合と同様にして式 (1-a), (1-b) を解く。式 (5) に対応する式として

$$
\begin{aligned}
\nabla^{4} F= & \left(E h^{2} \pi^{4} / a^{2} b^{2}\right) \sum_{p=0}^{\infty} \sum_{q=0}^{\infty} C_{p, q} \\
& \times \cos \frac{p \pi x}{a} \cos \frac{2 q \pi y}{b}
\end{aligned}
$$

が得られるが，この解としてつぎの $F$ が決定される。

$$
\begin{aligned}
F= & -\frac{2 M}{a^{3} h}\left(x-\frac{a}{2}\right)^{2}+E h^{2} \sum_{p=0}^{\infty} \sum_{q=0}^{\infty} \Phi_{p, q} \\
& \times \cos \frac{p \pi x}{a} \cos \frac{2 q \pi y}{b} \quad \ldots \ldots \ldots . . .
\end{aligned}
$$

ただし

$$
\Phi_{p, q}=C_{p, q} /\left(p^{2}+4 \beta^{2} q^{2}\right)^{2}, \beta=a / b
$$

つぎに式 (7) と同じような手法により基本式を導くと

$$
\begin{aligned}
\frac{\pi^{4}}{8 \beta^{2}} & \left(r^{2}+\beta^{2} s^{2}\right)^{2} b_{r s}-\frac{\partial M}{D} s^{2} \sum_{m}^{m \neq r} \frac{m r}{\left(m^{2}-r^{2}\right)^{2}} \\
\times & {\left[(-1)^{m+r}-1\right]\left(a_{m s}+b_{m s}\right) } \\
& -\frac{E h^{3} \pi^{2}}{32 D} \sum_{m} \sum_{n}\left(a_{m n}+b_{m n}\right)\{[2 m(n+s) \\
& +n(m+r)]^{2} \Phi_{m+r,(n+s) / 2}-[2 m(n+s) \\
& +(m-r) n]^{2} \Phi_{m-r,(n+s) / 2}-[2 m(n+s) \\
& -(r-m) n]^{2} \Phi_{r-m,(n+s) / 2}+[2 m(n-s) \\
& -(m+r) n]^{2} \Phi_{m+r,(n-s) / 2}-[2 m(n-s) \\
& -(m-r) n]^{2} \Phi_{m-r,(n-s) / 2}-[2 m(n-s) \\
& +(r-m) n]^{2} \Phi_{r-m,(n-s) / 2}+[2 m(s-n) \\
& +(m+r) n]^{2} \Phi_{m+r,(s-n) / 2}-[2 m(s-n) \\
& +(m-r) n]^{2} \Phi_{m-r,(n-s) / 2}-[2 m(s-n) \\
& -(r-m) n]^{2} \Phi_{r-m,(s-n) / 2}=0
\end{aligned}
$$

ただし

$$
\begin{aligned}
& \Phi_{p, q}(p<0 \text { or } q<0)=0 \\
& r=1,2,3, \cdots \cdots \quad s=1,3,5 \cdots
\end{aligned}
$$

\section{4. 電子計算機による数值計算例}

初期たわみのないせん断力を受ける正方形板を例とし て取り上げ，この場合についての基本式を近似的に解 き, ついで諸力学量すなわちたわみ $w$, 忘力 $\sigma_{x}, \sigma_{y}, \tau_{x y}$, 主応力 $\sigma_{1}, \sigma_{2}$, 主応力角 $\theta$, Huber von Mises-Hencky の比較応力 $\sigma_{M}$, Edge の相対変位 $u, v$ などを板の各 百分点についてそれぞれ求めた。 


\section{（1） 基本方程式の解法}

式 (9) において $a_{11}=0$ とおき,さらに $b_{13}$ と $b_{31}$ の対称性を考慮すればさらに簡単な 4 元 3 次 斉次代数方程式を導くことができる。これらの式 の解法の概要は

Step 1 線形理論による座屈点での各モード成 分の比を求め ${ }^{2)}$, これを

$$
\alpha_{c r}=h_{22} / b_{11}, \beta_{c r}=b_{33} / b_{11}, \gamma_{c r}=b_{31} / b_{33}
$$

とおく。

Step 2 荷重 $\lambda_{i}$ を座屈荷重 $\lambda_{c r}$ よりわずかだ 汁増大し

$$
\begin{aligned}
& \alpha_{i}=\alpha_{c r} \cdot[\delta+\phi \cdot \operatorname{FLOAT}(\mathrm{M})] \\
& \beta_{i}=\beta_{c r} \cdot[\delta+\phi \cdot \operatorname{FLOAT}(\mathrm{N})]
\end{aligned}
$$

ただし

$$
M=1,2, \cdots \cdots, 50 ; N=1,2, \cdots \cdots, 50
$$

として $\delta ， \phi$ を適当な值にとり変動させる。

Step $3 i$ 番目の方程式において $b_{22}, b_{33}, b_{31}$ をすべ て $\alpha_{i}, \beta_{i}, \gamma_{c r}$ と $b_{11}$ で表わし

$$
U_{l} \cdot b_{11}{ }^{3}+T_{l} \cdot b_{11}=0 \quad(l=1,2,3,4)
$$

の形にする。ここに $U_{l}, T_{l}$ は

$$
\begin{aligned}
& U_{l}=U_{l}\left(A_{j k}, \alpha_{i}, \beta_{i}, \gamma_{c r}, \lambda_{i}\right) \\
& T_{l}=T_{l}\left(A_{j k}, \alpha_{i}, \beta_{i}, \gamma_{c r}\right)
\end{aligned}
$$

$A_{j k}$ : 基本代数方程式の定数係数のつくる Matrix の要素

として表わされる。

Step 4

$$
\begin{aligned}
& b_{11}(l) \equiv R T(l)=\sqrt{-T_{l} / U_{l}} \\
& T_{l} \cdot U_{l}<0 \text { for } l=1,2,3,4
\end{aligned}
$$

Step 5 すべての $M, N$ の組み合わせについて $R T(l)$ を計算し相対的な誤差として

$$
\begin{aligned}
S S= & {[1-R T(2) / R T(1)]^{2} } \\
& +[1-R T(3) / R T(1)]^{2} \\
& +[1-R T(4) / R T(1)]^{2}
\end{aligned}
$$

を最小ならしめる $(M, N)$ の組を求めそのときの $\alpha, \beta$ を $\alpha^{*}, \beta^{*}$ として

$$
\begin{aligned}
& b_{11}=\frac{1}{4} \sum_{l}^{4} R T(l), b_{22}=\alpha^{*} b_{11}, b_{33}=\beta^{*} b_{11}, \\
& b_{31}=r_{c r} \cdot \beta^{*} b_{11}
\end{aligned}
$$

によって未知数を決定する。

Step $6 \quad \alpha_{c r}=\alpha^{*}, \beta_{c r}=\beta^{*}$ として初めの Step からく り返し順次大きな荷重に対して解を求める。

以上が計算過程であるが $b_{11}, b_{22}, b_{33}, b_{31}$ のうち $b_{33}$, $b_{31}$ の大きさは $b_{11}, b_{22}$ の大きさと比較すると十分小さ 、と考えられるため比 $b_{31} / b_{33}=r$ を座屈点のときの值に とって以後もこの比は変化しないものと考えた。実際は rの值は変動するであろうがその影響は一応小さいもの と考えられるし，このようないわば“しらみつぶし”式 の計算には時間を要するのでやむを得ない方法であろう
図一5 未知数 $b_{11}, b_{22}, b_{38}, b_{13}$ を求めるための プログラムフローチャート

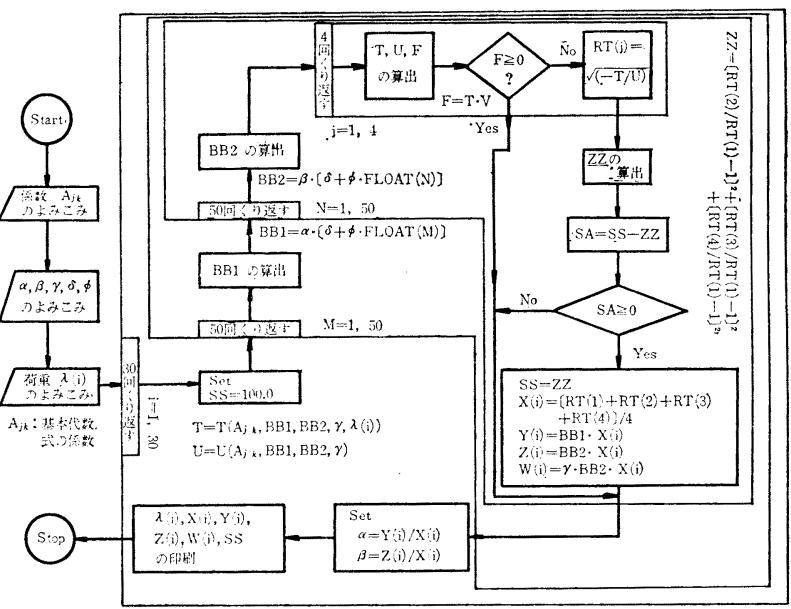

（もちろん後でこの点について検討を行なう必要があろ う)。図一5 は未知数決定のためのプログラム フローチ ヤートを示すものである。

\section{(2) 計算結果とその解析}

a) 基本方程式の解 表-2 に各荷重レベルに対す る解が示してある。解の大きさは座屈点の近傍において 急激に増加し, 荷重が大きくなるにしたがってその増加 率が鈍化する。

\begin{tabular}{r|l|l|l|l}
\multicolumn{5}{|c}{} \\
\hline$b^{2} h \tau / D$ & $b_{11}$ & \multicolumn{1}{|c}{$b_{22}$} & $b_{33}$ & $b_{13}=b_{31}$ \\
\hline 93.1 & 0.1754 & 0.05155 & 0.00697 & -0.01255 \\
93.2 & 0.2714 & 0.07948 & 0.01068 & -0.01923 \\
93.4 & 0.3645 & 0.1063 & 0.01417 & -0.02551 \\
93.7 & 0.4340 & 0.1263 & 0.01674 & -0.03013 \\
94.2 & 0.5403 & 0.1566 & 0.02050 & -0.03690 \\
94.6 & 0.6177 & 0.1784 & 0.02311 & -0.04160 \\
95.0 & 0.6625 & 0.1912 & 0.02466 & -0.04439 \\
96.0 & 0.8103 & 0.2315 & 0.02926 & -0.05739 \\
97.0 & 0.8919 & 0.2549 & 0.03188 & -0.05739 \\
98.0 & 0.9902 & 0.2829 & 0.03469 & -0.06244 \\
99.0 & 1.061 & 0.3033 & 0.03681 & -0.06626 \\
100.0 & 1.129 & 0.3227 & 0.03877 & -0.06979 \\
102.0 & 1.237 & 0.3533 & 0.04203 & -0.07566 \\
104.0 & 1.358 & 0.3879 & 0.04523 & -0.08141 \\
106.0 & 1.434 & 0.4137 & 0.04775 & -0.08596 \\
108.0 & 1.525 & 0.4398 & 0.05026 & -0.09047 \\
110.0 & 1.594 & 0.4646 & 0.05256 & -0.09461 \\
114.0 & 1.761 & 0.5131 & 0.05689 & -0.1024 \\
140.0 & 2.496 & 0.7612 & 0.07871 & -0.1417 \\
150.0 & 2.738 & 0.8434 & 0.08548 & -0.1539 \\
160.0 & 2.941 & 0.9152 & 0.09184 & -0.1653 \\
170.0 & 3.119 & 0.9899 & 0.09836 & -0.1771 \\
190.0 & 3.449 & 1.116 & 0.1098 & -0.1977 \\
210.0 & 3.776 & 1.231 & 0.1199 & -0.2159 \\
240.0 & 4.232 & 1.397 & 0.1334 & -0.2402 \\
270.0 & 4.573 & 1.540 & 0.1471 & -0.2648 \\
300.0 & 4.975 & 1.675 & 0.1579 & -0.2841 \\
340.0 & 5.385 & 1.831 & 0.1726 & -0.3106 \\
380.0 & 5.809 & 1.995 & 0.1862 & -0.3351 \\
440.0 & 6.337 & 2.198 & 0.2051 & -0.3692 \\
500.0 & 6.900 & 2.394 & 0.2211 & -0.3980 \\
\hline & & & &
\end{tabular}


b) たわみ 図一6 は板の中央点 $(0.5 \mathrm{a}, 0.5 \mathrm{a})$ の たわみ曲線であるがこれより板がせん断座屈してもたわ みは極端に大きくなることはないことがわかる。また図 -7 は特定の荷重レベルにおけるたわみ分布を示す立体 図である。

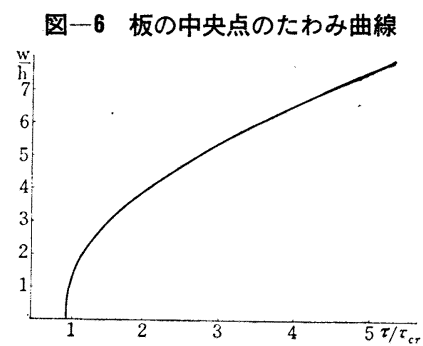

図-7 $\tau / \tau_{c r}=5.4$ のときのたわみ波形

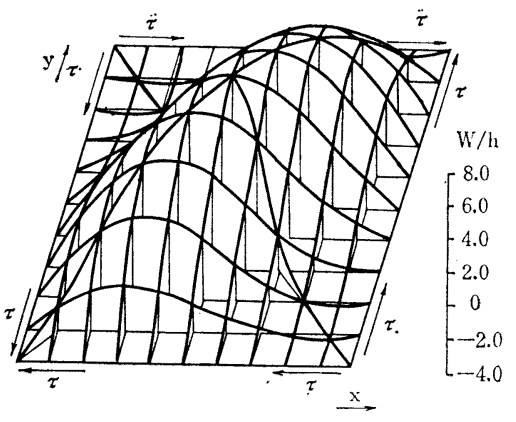

図-8 $\tau / \tau_{c r}=5.4$ のときの $\sigma_{x}$ の分布形

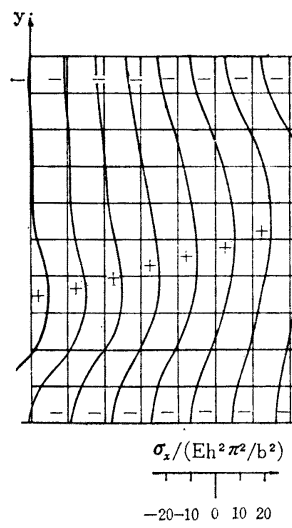

図一10(a) $\tau / \tau_{c r}=1$ のときの 主応力線図

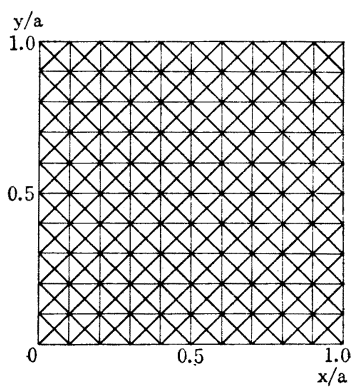

\section{c) 応力諸量}

・直応力 $\tilde{\sigma}_{x}, \tilde{\sigma}_{y}$ : 図一8 は荷重レベル $\tau / \tau_{c r}=5.4$ に対 する $\tilde{\sigma}_{x}$ の分布を示すものである。Edge においては外

図一9（a）板の対角線 $\boldsymbol{y}=\boldsymbol{x}$ 上の $\tau_{x y}$ の分布 $\tau_{x y} /\left(\mathrm{Eh}^{2} \pi^{2} / \mathrm{b}^{2}\right)$

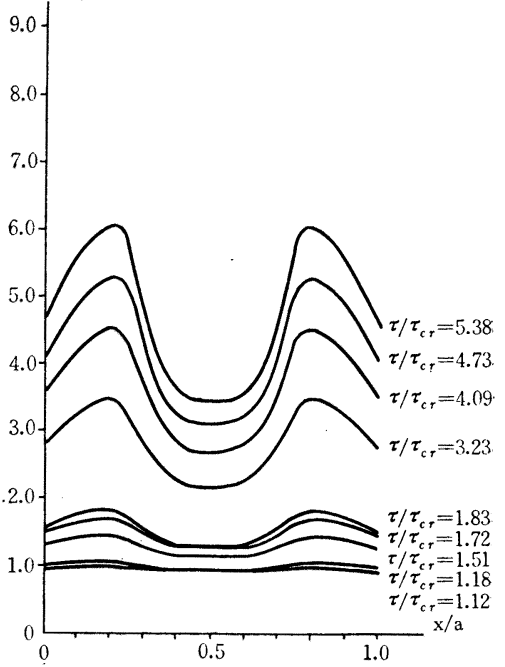

図-9（b）板の対角線 $\boldsymbol{y}=\boldsymbol{a}-\boldsymbol{x}$ 上の $\tau_{x y}$ の分布: $\tau_{x y} /\left(\mathrm{Eh}^{2} \pi^{2} / \mathrm{b}^{2}\right)$

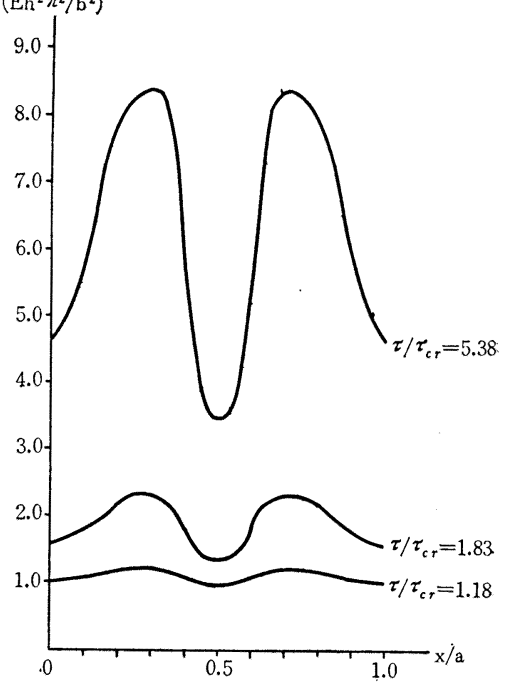

図-10 (c) $\tau / \tau_{c r}=5.38$ ときの 主応力線図

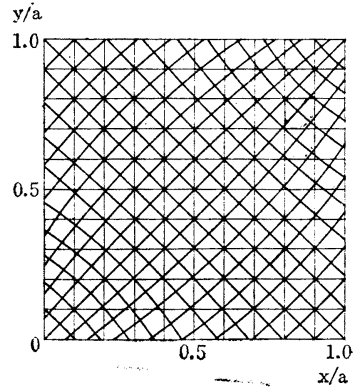

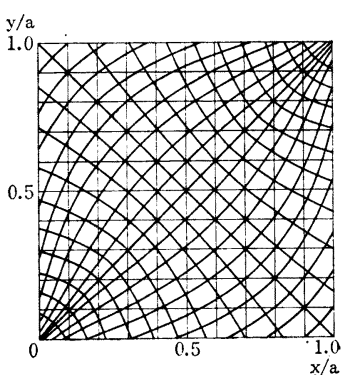


から拘束力が働いているものと考える。なお $\tilde{\sigma}_{y}$ の分布 は $\tilde{\sigma}_{x}$ の分布と対角線に関して対称なので省略する。

・せん断応力 $\tilde{\tau}_{x y}$ : 図一9 は板の 2 つの対角線上に生ず るせん断応力 $\tau_{x y}$ の分布を示すものである。

・主応力線：図一10 は3 つの荷重レベルに対する主応 力線図を示すものであり, 初め $45^{\circ}$ 方向に走っていた直 線群が変化するのが見受けられる。

-最大最小主応力の大きさ : 図一11 は板の $2 つ の$ 対角 線上に生ずる最大最小主応力の大きさの分布を示す。ま た 図一12 は特定の点に着目してそこに生ずる主応力の 大きさをプロットしたものであるが，中央付近ではある

図-11（a）板の対角線 $y=x$ 上の主応力の大きさ分布

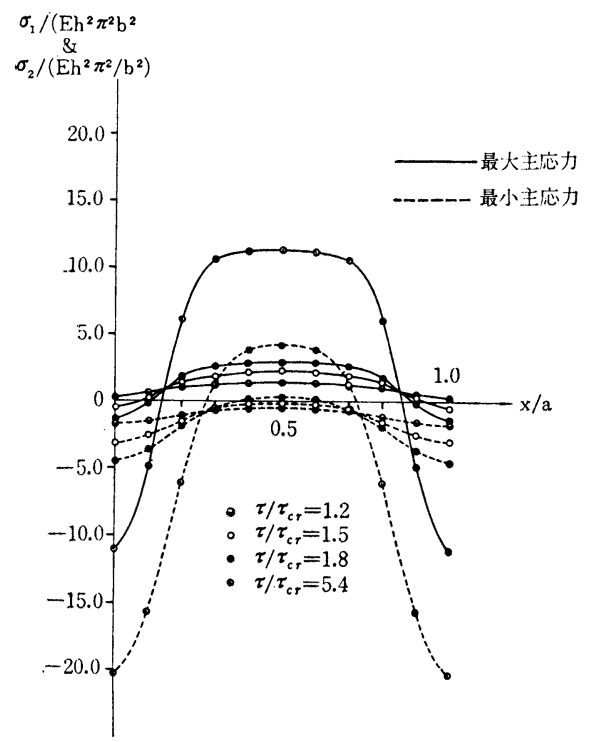

図一11（b）板の対角線 $\boldsymbol{y}=\boldsymbol{a}-\boldsymbol{x}$ 上の主応力の大きさ分布

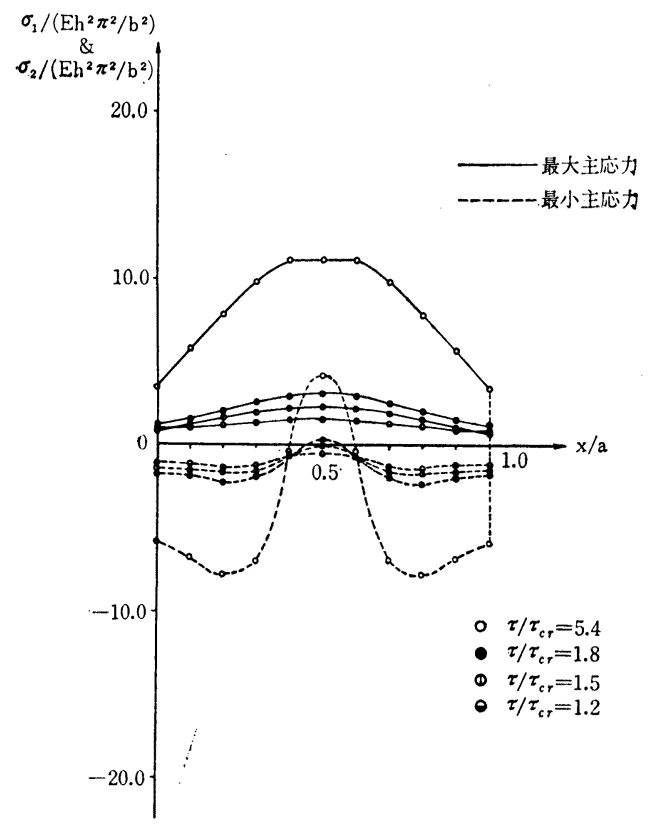

図-12（a）板内の点 $(0.3 \mathrm{a}, 0.3 \mathrm{a})$,

$(0.7 \mathrm{a}, 0.7 \mathrm{a})$ 上の主応力

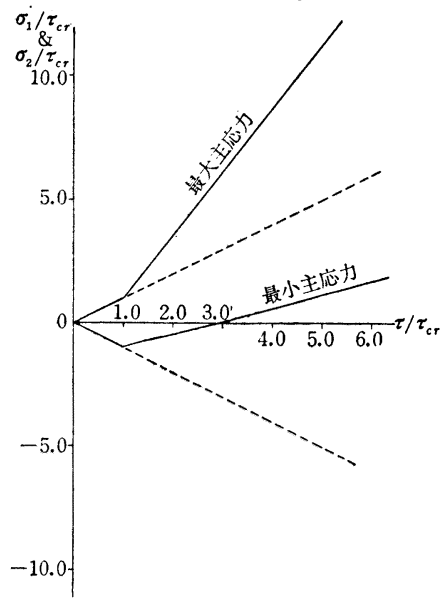

図-12 (b) 板内の点 $(0.4 \mathrm{a}, 0.6 \mathrm{a})$, $(0.6 \mathrm{a}, 0.4 \mathrm{a})$ 上の主応力
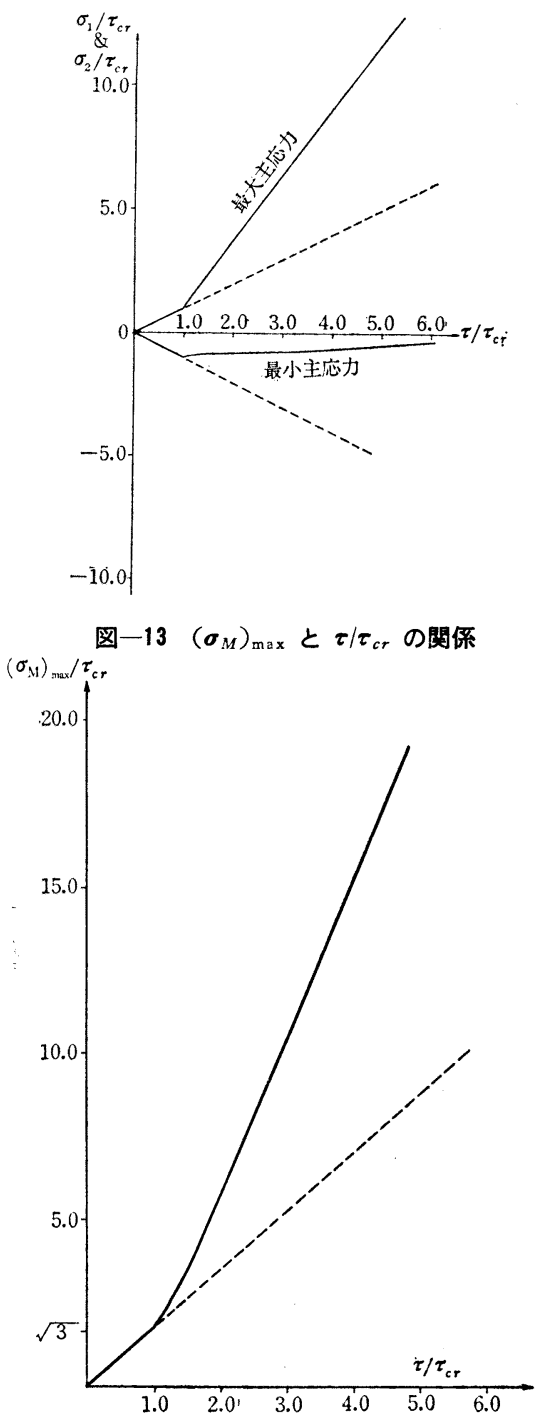


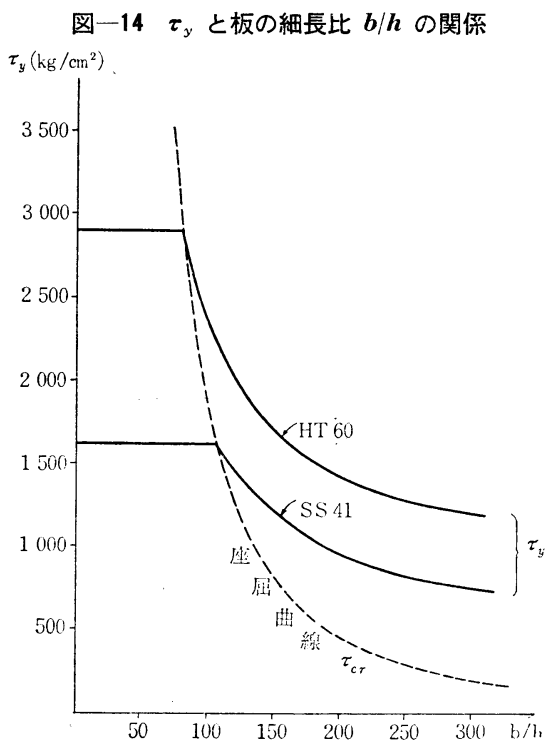

荷重以上に達すれば最小主応力も圧縮側から引張側へ変 化することが認められる。このことは関西橋梁鉄骨溶接 研究会が昭和 37 年に行なった実験の際にも見受けられ ていると思われる ${ }^{9)}$ 。しかし Skaloud 氏の計算結果では このようなことは全く現われていない。

- Huber-von Mises-Hencky の 比較応力 $\tilde{\sigma}_{M}: \tilde{\sigma}_{M}$ の最 大值 $\left(\sigma_{M}\right)_{\max }$ が降伏応力 $\sigma_{y}$ に達したとき板内の一点 で降伏すると考える。計算結果によれば $\left(\sigma_{M}\right)_{\max }$ の生 ずる箇所は荷重が座屈荷重の 1.5 倍ぐらいまでは点 (0.3 a， 0.7 a ) または点 $(0.7 \mathrm{a}, 0.3 \mathrm{a})$ でありそれ以 上に荷重を増大すれば点 (0.7 a , $1.0 \mathrm{a})$ または点 $(1.0$ $\mathrm{a}, 0.7 \mathrm{a})$, 点 $(0,0.3 \mathrm{a})$, 点 $(0.3 \mathrm{a}, 0)$ である。

- 降伏曲線 : 図一13 は上に述べた $\left(\sigma_{M}\right)_{\max }$ と荷重レベ ル $\tau / \tau_{c}$ との関係を図示したものである。つぎに 図一14 はこれを用いて腹板の細長比 $b / h$ と降伏応力度に達する ときの荷重レベル $\tau_{y}$ との関係を示す。ただし計算例と して関西橋梁鉄骨溶接研究会の行なった試験結果を利用 乙 SS $41\left(\sigma_{y}=2800 \mathrm{~kg} / \mathrm{cm}^{2}\right)$, HT $60\left(\sigma_{y}=5000 \mathrm{~kg} / \mathrm{cm}^{2}\right)$ の 2 つをとっている。この図によって明らかに HT 60 の方が SS 41 よりも有利であることがわかる。

図-15 Edge の相対変化 $u, v$

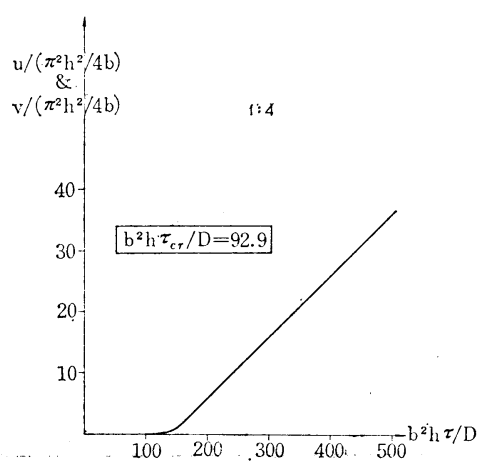

d) Edge の相対変位 式 (12) を計算して相対変 位 $u, v$ の大きさを各荷重レベルについてプロットすれ ば図一15 のようになる。

\section{5.むすび}

以上のせん断耐荷力に関する計算結果よりつぎのこと が明らかになった。

（1）荷重 $\tau$ が座屈荷重 $\tau_{c r}$ を越えて増大しても極端 に大きなたわみは生じない。

（2）荷重が $\tau_{c r}$ から増大するにしたがって，たわみ 波形において斜め方向の細長い帯状の起伏が次第に顕著 になる。

（3）座屈後荷重の增大とともに相対する板の端辺は 互いに接近するように変形するが，この相対変位は荷重 がェ $r$ の 5 倍ほどになると板の細長比 $100 ， 200,300$ に 対してそれぞれ板厚の 0.9 倍, 0.4 倍, 0.3 倍ぐらいの 大きさになる。したがってもし板の境界にそってフラン ジや補剛材が配置されておればこの相対変位は拘束され ることになるので実際の腹板の耐荷力はいま考えている 板のそれと比較して大きい。

（4）荷重の増大とともに板には膜引張力が発達す る。そのとき最大主応力と最小主応力の大きさの差は次 第に大きくなり，板の中央半分ぐらいの領域においては 明確な斜め張力の場が認められる。荷重が非常に大きく なると最小主忘力も圧縮側から引張側へと変化するよう になるが，この現象は板の境界部材の岡度と腹板のそれ との比によって全く異なる可能性があることを示唆して おく。

（5）板のせん断力による座屈後の「荷重一たわみ曲 線」,「荷重一応力曲線」を描くと前者はいわば放物線形 の曲線であるのに対して後者はほぼ直線形を示す。

（6）現在の鋼構造物設計示方書によればせん断耐荷 力に関しては高張力鋼の使用によるメリットは大きくな い。しかし実際にはもし降伏応力に対して一定の安全率 を有するように設計すれば本論文に述べられたように普 通鋼よりも高張力鋼の方が有利であることが結論づけら れる。しかも実際の腹板は堅固な上下フランジと補剛材 によって連続的に支持されているので安定性は解析の対 象となった板よりは明らかに良好であり，高張力鋼の有 益性が生かせよう。

今後さらに本研究において考慮されたいろんな場合に ついてはもちろん他の複雑な場合についても数值計算を 行なって資料としたいと思う。
6. 記
号
$x, y, z:$ 直交座標, $Z$ 注板厚方向
$M:$ 外力曲げモーメント
$\sigma_{x}, \sigma_{y}, \tilde{\sigma}_{x}, \tilde{\sigma}_{y}: x-, y$-軸に平行な直応力度成分であり 


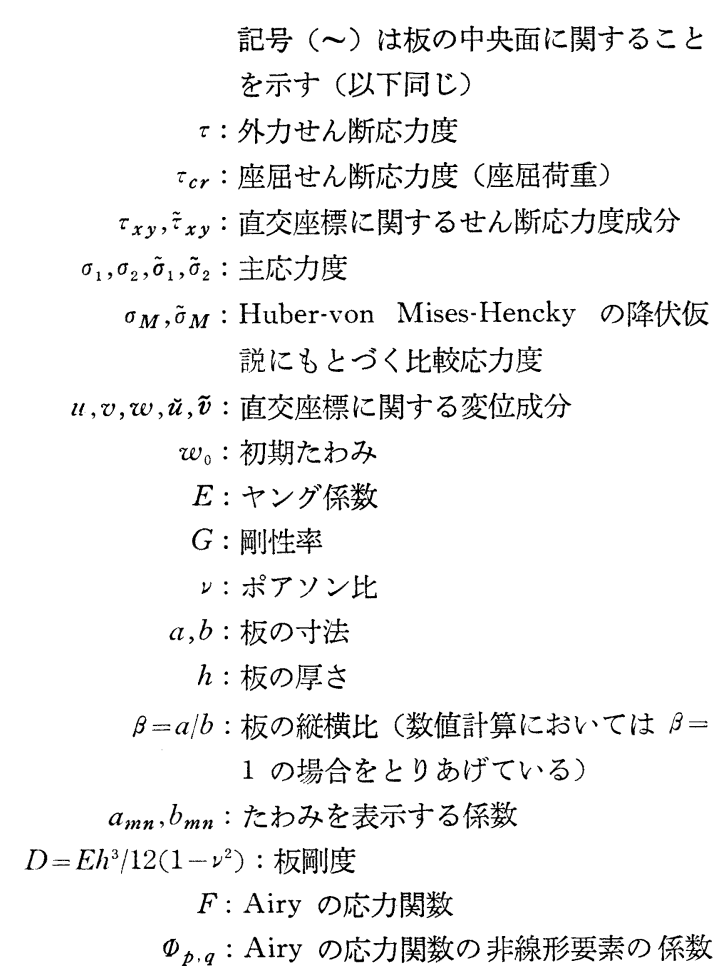

1) Novozhilov, V.V.: "Foundations of Nonlinear Theory of Elasticity", 1953.

2) Mansfield, E.H. : "The Bending and Stretching of Plates", pp. 99-133, Vol. 6 of International Series of Monographs on Aeronautics and Astronautics.

3) Langhaar, H.L. : "Energy Methods in Applied Mechanics", pp. 159-164, John Wiley and Sons, Inc., 1962 .

4) Basler, K. : "Strength of Plate Girders in Shear", Proceedings of ASCE ST7, 1961.

5) Basler, K. and Thürlimann, B. : "Strength of Plate Girders in Bending", Proceedings of ASCE ST 6, 1961.

6) Massonnet, C.E.L. : "Stability Considerations in the Design of Steel Plate Girders", Proceedings of ASCE ST 1, 1960.

7) Yamaki, N. : "Postbuckling Behaviour of Rectangular Plates with Small Initial Curvature Loaded in Edge Compression", Journal of Applied Mechanics September, 1959, June 1960.

8) Skaloud, M. : "Design of Webplates of Steel Girder with Regard to the Postbuckling Behaviour (Analytical Solution), "The Structural Engineer, December. 1962.

9）「プレートガーダーの耐荷力に関する理論と実験」,関西橋 梁鉄骨溶研接究会, 1965 年 7 月

(1966.5.11 · 受付) 